\title{
THE EARLY DIAGNOSIS OF RICKETS
}

BY

\section{J. D. GRAY, M.D., and F. STEPHEN CARTER, M.D., B.Chir.D.C.H. (From the Belgrave Hospital for Children, London)}

With the widespread application of the knowledge of the relationship of vitamin $D$ to rickets, the occurrence of the clinical picture familiar from Glisson's time onwards has nearly disappeared. In its place we are faced with changes brought about by a suboptimal intake of the necessary vitamin. Unfortunately the physical signs on which a diagnosis depends mimic the wide variation of normal to be found in infants. Cocil (1940) thus sums up the position: 'Clinical appraisal of the departure from normal in the rib-cartilage junction is difficult. A common clinical error is to diagnose rickets where no rickets is present.' The reverse is true. The same statement is applicable to the closing of the fontanelle, the eruption of teeth, and the width of the lower end of the radius. 'The clinical diagnosis of rickets based upon enlarged epiphyses and bow-legs is often unreliable.' (Price, 1946).

The radiological appearance of the lower end of the radius and ulna is often accepted as the arbiter. This is open to question, for the British Paediatric Association (1944) in an enquiry into the incidence of rickets in war-time, using a panel of experienced paediatricians and radiologists, found a clinical incidence of 12.5 per cent. to a radiological 0.5 per cent. Rackow (1949) says:

- The wrist joint in the infant is generally accepted by radiologists as being the most satisfactory for $x$-ray study in the diagnosis of rickets. It offers no technical difficulties in the making of the radiograph and when changes in the bone have occurred they are invariably present at the lower end of the radius and ulna. Being a small joint, all parts remain comparatively close to the film, so that as long as movement is excluded, the definition of bone structure is sharp.

'The florid and active form of rickets is readily diagnosed radiologically, and the diagnostic problem now mainly concerns itself with slighter degrees of rachitic change.

'The early radiological changes in the bone are mainly changes of degree and not of kind. Thus, slight expansion of the diaphyses of the radius and ulna is already present at the lower end of the normal bone. The uina also normally shows slight cupping; osteoporosis may be simulated by slight over-penetration of the radiograph. For these reasons, and because radiological change of any kind in bone, which is due to systemic disorder, may take several weeks to establish itself, the early radiological diagnosis of rickets may be uncertain, and many cases can only be classed as doubtful.'

The plasma-alkaline-phosphatase has been accepted by many observers as a reliable means of detecting active and latent rickets (Cantarow and Trumper, 1945). In this respect, most investigators have used Bodansky's method for determining the phosphatase content of the blood in rickets. It has two disadvantages for routine use in paediatrics in that it requires well over an hour for a determination and it needs $2 \mathrm{ml}$. of serum. On the other hand, the King-Armstrong method can be completed in twenty-five minutes and requires only $0.4 \mathrm{ml}$. plasma. An alternative argument in favour of Bodansky's method is that it combines an estimation of the serum inorganic phosphate as well as the phosphatase. However, it has been our experience that the inorganic phosphate in the majority of cases of early rickets is within normal limits although the phosphatase is increased. Barnes et al. (1946) noted that in $\mathbf{4 0}$ per cent. of their cases of rickets the calcium and phosphorus levels were normal Josefsson (1941) has shown that active rickets may be present in spite of normal calcium and phosphorus levels, but in the healing stage the phosphorus level may be low. Thus, there seems to be considerable evidence that the blood calcium phosphorus product is unreliable as a means of detecting early rickets. Because of the arguments presented here, the plasma alkaline phosphatase has been estimated by the King-Armstrong method in all cases of clinically suspected rickets seen at the Belgrave Hospital for Children during the last two and a half years. The normal range is 0-10 units in the adult. Little information was available as to the normal and pathological ranges to be found in young children, for only two references were found which had a bearing on rickets. May and Wygant (1939) considered that rickets could not be diagnosed under 55 King-Armstrong units of phosphatase activity, and on the other hand Corner (1944) put the normal range at 3-10 units with no relation to age, and suggested that readings of 15 units or over were diagnostic of rickets. In our experience, the first was too high and the latter too low. An attempt, therefore, has been made to assess the normal range, to relate the chinical condition to King-Armstrong units of phosphatase activity, and to use the phosphatase content as a guide to treatment. 
TANE 1

ANALYSIS OF CASES OF CLINICAL RICKETS SHOWING PLASMA PHOSPHATASE LEVELS AND RESPONSE TO VITAMIN D

\begin{tabular}{|c|c|c|c|c|c|c|c|c|c|}
\hline \multirow{3}{*}{$\frac{\text { No. }}{1}$} & \multirow{3}{*}{$\frac{\text { Sex }}{\text { F. }}$} & \multirow{3}{*}{$\frac{\text { Vitamin D }}{\text { Givent }}$} & \multirow{3}{*}{$\frac{\text { Age }}{1 \text { yr. } 7 \text { moaths }}$} & \multirow{3}{*}{$\frac{\text { Signs }}{\mathbf{S}+\mathbf{S}+*}$} & \multicolumn{3}{|c|}{ Phosphatase Units } & \multirow[b]{2}{*}{ Treatment } & \multirow[b]{2}{*}{ Remarks } \\
\hline & & & & & \multicolumn{2}{|c|}{ Date } & \multirow{2}{*}{$\frac{\text { No. }}{25}$} & & \\
\hline & & & & & $\begin{array}{l}16 \text { Jan., } \\
19 \text { Feb., } \\
19 \text { Mar., }\end{array}$ & $\begin{array}{l}1947 \\
1947 \\
1947\end{array}$ & & Cakiferol 200,000 units & $\begin{array}{l}\text { Radiograph showed epiphyses } \\
\text { rachitic }\end{array}$ \\
\hline 2 & F. & $?$ & 11 months & $\mathbf{B}+\mathbf{F 1}$ & $\begin{array}{l}21 \text { Nov., } \\
28 \text { Feb., }\end{array}$ & $\begin{array}{l}1946 \\
1947\end{array}$ & $\begin{array}{l}23 \\
18\end{array}$ & Radiostoleum $5 \mathrm{ml}$. drily & - \\
\hline 3 & M. & None & 5 months & $\mathbf{B}+\mathbf{C}+\mathbf{E}+$ & $\begin{array}{l}4 \text { Dec., } \\
31 \text { Mar., }\end{array}$ & $\begin{array}{l}1946 \\
1947\end{array}$ & 24 & Cakciferol 200,000 units & \\
\hline 4 & M. & $?$ & 1 yr. 3 months & $\mathbf{B}+\mathbf{S}+$ & $\begin{array}{l}4 \text { June, } \\
23 \text { Aug, } \\
5 \text { Jan, } \\
5 \text { April, }\end{array}$ & $\begin{array}{l}1947 \\
1947 \\
1948 \\
1948\end{array}$ & $\begin{array}{l}30 \\
23 \\
20 \\
17\end{array}$ & Adexolin $30 \mathrm{~m}$. daily & \\
\hline 5 & $\mathbf{M .}$ & $?$ & 1 yr. 7 months & $\mathbf{B}+\mathbf{B}=$ & $\begin{array}{l}7 \text { May, } \\
7 \text { July, }\end{array}$ & $\begin{array}{l}1947 \\
1947\end{array}$ & $\begin{array}{l}76 \\
17\end{array}$ & Calciferol 200,000 by 3 & $\begin{array}{l}\text { Radiograph showed epiphyses } \\
\text { rachitic }\end{array}$ \\
\hline 6 & $\mathbf{M}$. & Given & 1 yr. 11 months & $\mathbf{B}+\mathbf{F}+\mathbf{C}+$ & 26 July, & $\begin{array}{l}1948 \\
1948\end{array}$ & $\mathbf{6 4}$ & Calciferol 200,000 units & \\
\hline 7 & $\mathbf{M}$. & $?$ & 1 yr. 6 months & $\mathbf{B}+\mathbf{B} \mathbf{s}$ & 26 Jan., & $\begin{array}{l}1948 \\
1948\end{array}$ & $\begin{array}{l}36 \\
21\end{array}$ & Calciferol 200,000 units & Radiograph normal \\
\hline 8 & $\mathbf{M}$. & $?$ & 1 yr. 5 months & $\mathbf{B}+\mathbf{F} \div$ & $\begin{array}{l}28 \text { June, } \\
29 \text { July, }\end{array}$ & $\begin{array}{l}1948 \\
1948\end{array}$ & $\begin{array}{l}38 \\
25\end{array}$ & Calciferol 200,000 units & Radiograph normal \\
\hline 9 & $\mathbf{F}$. & $?$ & 2 yrs. 6 months & $\mathbf{B}+$ & $\begin{array}{l}16 \text { Jan., } \\
13 \text { Feb., }\end{array}$ & $\begin{array}{l}1947 \\
1947\end{array}$ & $\begin{array}{l}25 \\
19\end{array}$ & Calciferol 200,000 units & . \\
\hline 10 & $\mathbf{M}$. & $?$ & 8 months & $\mathbf{B} \div \mathbf{F} \div \mathbf{C}+$ & $\begin{array}{l}30 \text { Sept., } \\
25 \text { Oct., } \\
24 \text { Nov., }\end{array}$ & $\begin{array}{l}1946 \\
1946 \\
1946\end{array}$ & $\begin{array}{l}29 \\
42 \\
46\end{array}$ & Ostelin $30 \mathrm{~m}$. daily & $\begin{array}{l}\text { Radiograph showed recalcify- } \\
\text { ing riclets }\end{array}$ \\
\hline 11 & $\mathbf{M}$. & $?$ & 3 yrs. 6 months & Bs & $\begin{array}{l}12 \text { Juky, } \\
4 \text { Oct. }\end{array}$ & $\begin{array}{l}1948 \\
1948\end{array}$ & $\begin{array}{r}\mathbf{3 0} \\
\mathbf{2 0}\end{array}$ & Calciferol 200,000 units & \\
\hline 12 & M. & $?$ & 1 yr. 3 months & $\mathbf{B}+\mathbf{S}+\mathbf{F} \mathbf{1}$ & $\begin{array}{l}29 \text { Apr., } \\
16 \text { June, } \\
13 \text { July, } \\
18 \text { Oct., } \\
20 \text { Dec., }\end{array}$ & $\begin{array}{l}1948 \\
1948 \\
1948 \\
1948 \\
1948\end{array}$ & $\begin{array}{l}30 \\
42 \\
58 \\
37 \\
18\end{array}$ & Calciferol 200,000 by 3 & \\
\hline 13 & M. & $?$ & 1 yr. 11 months & $\mathbf{F}+\mathbf{B} \mathbf{s}$ & $\begin{array}{l}11 \text { Ang., } \\
6 \text { Oct. }\end{array}$ & $\begin{array}{l}1948 \\
1948\end{array}$ & 44 & Cod-liver oil dr. 2 daily & \\
\hline 14 & $\mathbf{M}$. & Given & 1 yr. 8 months & $\mathbf{B}-\mathbf{B}-\mathbf{B s}$ & $\begin{array}{l}6 \text { Aug., } \\
5 \text { Oct, } \\
16 \text { Nov., } \\
28 \text { Dec., }\end{array}$ & $\begin{array}{l}1948 \\
1948 \\
1948 \\
1948\end{array}$ & $\begin{array}{l}51 \\
30 \\
38 \\
39\end{array}$ & Calciferol 200,000 by 3 & : \\
\hline 15 & $\mathbf{F}$. & $?$ & 1 yr. 7 months & $\mathbf{B}+\mathbf{B}+\mathbf{B} \mathbf{S}+$ & $\begin{array}{l}6 \text { Oct., } \\
15 \text { Nov., } \\
16 \text { Dec. }\end{array}$ & $\begin{array}{l}1948 \\
1948 \\
1948\end{array}$ & $\begin{array}{l}42 \\
43 \\
22\end{array}$ & $\begin{array}{l}\text { Calciferol tab. co, t.d.s. } \\
\text { (S00 units, Vit. D per } \\
\text { tablet) }\end{array}$ & \\
\hline 16 & F. & $?$ & 1 yr. 1 month & $\mathbf{B}+\mathbf{E}+\mathbf{B s F 1}$ & $\begin{array}{l}11 \text { Nov., } \\
15 \text { Dec., }\end{array}$ & $\begin{array}{l}1948 \\
1948\end{array}$ & $\begin{array}{l}38 \\
16\end{array}$ & Calciferol 200,000 by. 2 & . \\
\hline 17 & $\mathbf{M}$. & $?$ & 1 yr. 5 months & $\mathbf{B} \div \mathbf{E}+\mathbf{F} \mathbf{1}$ & $\begin{array}{l}4 \text { Jan., } \\
8 \text { Feb., }\end{array}$ & $\begin{array}{l}1948 \\
1948\end{array}$ & 46 & Calciferol 200,000 units & \\
\hline $\begin{array}{l}18 \\
19\end{array}$ & $\begin{array}{l}\mathbf{M} \text {. } \\
\mathbf{M} \text {. }\end{array}$ & $\begin{array}{l}\text { Given } \\
\text { Given }\end{array}$ & $\begin{array}{l}1 \text { yr. } 3 \text { months } \\
1 \text { yr. } 9 \text { months }\end{array}$ & $\begin{array}{l}\mathbf{B}+\mathbf{B}+ \\
\mathbf{B}+\mathbf{E}+\mathbf{F}+\end{array}$ & $\begin{array}{l}25 \text { Ang, } \\
6 \text { Dec., } \\
7 \text { May, } \\
9 \text { June, }\end{array}$ & $\begin{array}{l}1948 \\
1948 \\
1948 \\
1948\end{array}$ & $\begin{array}{l}\mathbf{5 8} \\
22 \\
32 \\
22\end{array}$ & $\begin{array}{l}\text { Calciferol } 200,000 \text { by } 2 \\
\text { Calciferol } 200,000 \text { units }\end{array}$ & Radiograph showed ? rickets \\
\hline 20 & F. & Given & 1 yr. 2 months & $\mathbf{E}+\mathbf{F}+$ & $\begin{array}{l}12 \text { Mar., } \\
7 \text { May, } \\
16 \text { Jumes }\end{array}$ & $\begin{array}{l}1947 \\
1947 \\
1947\end{array}$ & $\begin{array}{l}36 \\
23 \\
17\end{array}$ & Calciferol 200,000 units & $\begin{array}{l}\text { Radiograph showed bealing } \\
\text { rickets }\end{array}$ \\
\hline 21 & F. & Given & 1 yr. 4 months & $\mathbf{B}+\mathbf{B s}$ & & - & 45 & & $\begin{array}{l}\text { Radiograph showed epiphyses } \\
\text { rachitic }\end{array}$ \\
\hline 22 & F. & None & 1 yr. 4 months & $\mathbf{F}+\mathbf{F 1}$ & & & 33 & & \\
\hline 23 & F. & Given & 1 yr. & $\mathbf{B}+\mathbf{F}+\mathbf{F} \mathbf{1}$ & & & 49 & & \\
\hline 24 & F. & $?$ & 1 yr. 8 months & $\mathbf{B}+$ & - & & 49 & & \\
\hline 25 & M. & Given & 7 months & $\mathbf{F}+\mathbf{C}+\mathbf{F} \mathbf{1}$ & & & 36 & & \\
\hline 26 & F. & $?$ & 2 yrs. 3 months & $\mathbf{B}+\mathbf{B s F 1}$ & & & 37 & & \\
\hline
\end{tabular}


TAME 1 - cont.

\begin{tabular}{|c|c|c|c|c|c|c|c|c|}
\hline \multirow[b]{2}{*}{ No. } & \multirow[b]{2}{*}{ Sex } & \multirow[b]{2}{*}{ Vitamin D } & \multirow[b]{2}{*}{ Age } & \multirow[b]{2}{*}{ Signs } & \multicolumn{2}{|c|}{ Phosphatase Units } & \multirow[b]{2}{*}{ Treatment } & \multirow[b]{2}{*}{ Remarks } \\
\hline & & & & & Date & No. & & \\
\hline $\begin{array}{l}27 \\
28\end{array}$ & $\mathbf{F}$. & $\begin{array}{l}\text { None } \\
\text { None }\end{array}$ & $\begin{array}{l}11 \text { months } \\
1 \text { yr. } 4 \text { months }\end{array}$ & $\begin{array}{l}\mathbf{B}-\mathbf{E}+\mathbf{C}- \\
\mathbf{B}+\mathbf{B} \mathbf{C}-\end{array}$ & & 32 & & \\
\hline 29 & F. & None & 7 months & $\mathbf{B}_{-}$ & & 30 & & \\
\hline 30 & F. & $?$ & 1 yr. & $\mathbf{B}-\mathbf{F} \mathbf{1}$ & & 27 & & $\begin{array}{l}\text { Radiograph showed epiphyses } \\
\text { rachitic }\end{array}$ \\
\hline 31 & M. & None & 2 yrs. 3 months & $\mathbf{E}-\mathbf{F 1}$ & & 30 & & \\
\hline 32 & M. & Given & $1 \mathrm{yr} .6$ months & $\mathbf{B} \div$ & & 26 & & $\begin{array}{l}\text { Radiograph showed epiphyses } \\
\text { rachitic }\end{array}$ \\
\hline 33 & M. & Given & 4 months & $\mathbf{B} \div \mathbf{C} \div$ & & 26 & & \\
\hline 34 & M. & None & 1 yr. 3 months & $\mathbf{E}+\mathbf{B s}$ & & 30 & & \\
\hline 35 & M. & $?$ & 2 yrs. & $\mathbf{E} \div \mathbf{B s F 1}$ & & 32 & & \\
\hline 36 & $\mathbf{F}$. & $?$ & 2 yrs. & $\mathbf{B}+\mathbf{E}+\mathbf{B s}$ & & 26 & & Radiograph normal \\
\hline 37 & M. & None & 2 yrs. 1 month & $\mathbf{B}+\mathbf{F} \mathbf{1}$ & & 32 & & \\
\hline 38 & M. & $?$ & 1 yr. 3 months & $\mathbf{B}+\mathbf{E}+$ & & 29 & & \\
\hline 39 & M. & Given & 1 yr. 3 months & $\mathbf{B}+\mathbf{F}+$ & & 29 & & \\
\hline 40 & F. & None & 2 yrs. 6 months & $\mathbf{B} \div \mathbf{B s F}-$ & & 31 & & \\
\hline 41 & M. & $?$ & 1 yr. 9 months & $\mathbf{B}+\mathbf{E}+$ & & 33 & & \\
\hline 42 & F. & $?$ & $1 \mathrm{yr} .6$ months & $\mathbf{B}+\mathbf{B s}$ & & 32 & & \\
\hline 43 & M. & $?$ & 9 months & $\mathbf{B}+\mathbf{F}+\mathbf{F} \mathbf{1}$ & & 27 & & \\
\hline 44 & $\mathbf{M}$. & None & 4 months & $\mathbf{F 1}$ & & 37 & & $\begin{array}{l}\text { Radiograph showed epiphyses } \\
\text { rachitic }\end{array}$ \\
\hline 45 & M. & Given & 1 yr. 8 months & $\mathbf{B}+\mathbf{F}+\mathbf{F} \mathbf{1}$ & & 54 & & $\begin{array}{l}\text { Radiograph showed rachitic } \\
\text { changes }\end{array}$ \\
\hline 46 & F. & $?$ & 6 months & $\mathbf{B}+\mathbf{E}+\mathbf{F} \mathbf{1}$ & & 30 & & $\begin{array}{l}\text { Radiograph showed epiphyses } \\
\text { rachitic }\end{array}$ \\
\hline
\end{tabular}

- In the tables:

$\mathrm{B}+=$ beading at the costochondral junction. This was assessed as far as possible on the recommendations of Dalyell and Mackay (1922), and beading has not been indicated unless it could be graded $1 \frac{1}{2}-2$ by their standards.

Bs = bossing of the skull.

$\mathrm{C}_{+}=$craniotabes.

E $+=$ enlarged epiphyses at the wrists.

St = Harrison's sulcus.

$F+=a$ fontanelle larger than age permits.

F1 = muscle tone poor.

+ Where the mother was insistent that cod-liver oil had been given it is stated as 'given'; doubtful evidence has been indicated by a question mark.

\section{Method}

The plasma phosphatase was determined in forty-six apparently healthy children from one month to three years old with no clinical signs of rickets. The average obtained for this group was 17 King-Armstrong units with a spread of 11-20. Ten children of three to five years averaged 12 units with a spread of 8-18 units. In thirteen of the controls picked at random, radiographs of radial and ulnar epiphyses appeared normal.

We have not included three cases of florid rickets in which the phosphatase levels fell between 80 and 220 units as diagnostic confirmation was not required.

One of us (F.S.C.) is responsible for the clinical diagnoses in all the cases reported.

\section{Discussion}

The contention that rickets cannot be diagnosed under 55 King-Armstrong units of phosphatase activity is not borne out by the findings in the series of cases presented. In most the diagnostic titre lay between 30 and 40 units, and with the institution of specific therapy the response was prompt and marked. On the other hand, it has not been possible to substantiate clearly Corner's claim that rickets could be related to findings in the 15-20 units range. Setting aside the control values given in this paper and considering the problem from different aspects, the following points are put forward to strengthen the view that her figures for normality are too low for the first two years of life. Barnes and Munks (1940) in establishing values for infants 
TARE 2

ANALYSIS OF CASES WITH SYMPTOMS BUT NO SIGNS

\begin{tabular}{|c|c|c|c|c|c|c|c|c|c|}
\hline \multirow{2}{*}{$\frac{\text { No. }}{1}$} & \multirow{2}{*}{$\frac{\text { Sex }}{\text { M. }}$} & \multirow{2}{*}{$\frac{\text { Vitamin D }}{\text { Given }}$} & \multirow{2}{*}{$\frac{\text { Age }}{1 \text { yr. } 2 \text { months }}$} & \multirow{2}{*}{$\begin{array}{r}\text { Signs } \\
\text { Irritable }\end{array}$} & \multicolumn{3}{|c|}{ Phosphatase Units } & Treatment & \multirow[t]{2}{*}{ Remarks } \\
\hline & & & & & $\begin{array}{l}20 \text { Oct., } \\
19 \text { Nov., }\end{array}$ & $\begin{array}{l}1948 \\
1948\end{array}$ & $\begin{array}{l}35 \\
27\end{array}$ & $\begin{array}{l}\text { Tab. Cakiferol Co. t.d.s. } \\
\text { (5 units, Vit. D. per tab.) }\end{array}$ & \\
\hline 2 & $\mathbf{F}$. & None & 1 yr. 9 months & Irritable & $\begin{array}{l}14 \text { Oct., } \\
30 \text { Nov., } \\
25 \text { Jan., }\end{array}$ & $\begin{array}{l}1948 \\
1948 \\
1949\end{array}$ & $\begin{array}{l}29 \\
23 \\
23\end{array}$ & $\begin{array}{l}\text { Tab. Calciferol Co. t.d.s. } \\
\text { (5 units, Vit. D. per tab.) }\end{array}$ & \\
\hline 3 & $\mathbf{F}$. & None & 1 yr. 8 months & $\begin{array}{l}\text { Irritable } \\
\text { Sweats }\end{array}$ & $\begin{array}{l}27 \text { May, } \\
25 \text { June, } \\
28 \text { July, } \\
29 \text { Oct., } \\
27 \text { Jan., }\end{array}$ & $\begin{array}{l}1948 \\
1948 \\
1948 \\
1948 \\
1949\end{array}$ & $\begin{array}{l}38 \\
24 \\
45 \\
35 \\
17\end{array}$ & Cakiferol 200,000 by 3 & Radiograph normal \\
\hline 4 & M. & $?$ & 1 yr. 4 months & Head sweats & $\begin{array}{l}26 \text { May, } \\
30 \text { June, } \\
26 \text { July, } \\
23 \text { Aug., } \\
20 \text { Sept., } \\
20 \text { Jan., }\end{array}$ & $\begin{array}{l}1948 \\
1948 \\
1948 \\
1948 \\
1948 \\
1949\end{array}$ & $\begin{array}{l}33 \\
36 \\
35 \\
42 \\
34 \\
26\end{array}$ & Cakiferol 200,000 by 5 & Radiograph showed ? rickets \\
\hline 5 & $\mathbf{M}$. & None & 9 months & No symptoms & $\begin{array}{l}18 \text { Nov., } \\
1 \text { Jan., } \\
23 \text { June, }\end{array}$ & $\begin{array}{l}1946 \\
1947 \\
1947\end{array}$ & $\begin{array}{l}33 \\
15 \\
17\end{array}$ & Radiostoleum $5 \mathrm{ml}$. daily & $\begin{array}{l}\text { Radiograph showed epiphyses } \\
\text { rachitic } \\
\text { Radiograph showed epiphyses } \\
\text { normal }\end{array}$ \\
\hline 6 & F. & None & 6 months & Irritable & $\begin{array}{l}24 \text { Aug., } \\
23 \text { Sept., }\end{array}$ & $\begin{array}{l}1948 \\
1948\end{array}$ & $\begin{array}{l}31 \\
16\end{array}$ & Cakciferol 200,000 units & \\
\hline $\begin{array}{l}7 \\
8\end{array}$ & $\begin{array}{l}\text { M. } \\
\text { F. }\end{array}$ & $\begin{array}{c}? \\
\text { None }\end{array}$ & $\begin{array}{l}11 \text { months } \\
4 \text { months }\end{array}$ & $\begin{array}{l}\text { Irritable } \\
\text { Irritable } \\
\text { Head sweats }\end{array}$ & $\begin{array}{l}9 \text { July, } \\
7 \text { Apr., } \\
25 \text { Mar., } \\
11 \text { May, }\end{array}$ & $\begin{array}{l}1947 \\
1948 \\
1948 \\
1948\end{array}$ & $\begin{array}{l}27 \\
20 \\
28 \\
20\end{array}$ & $\begin{array}{l}\text { Adexolin m. } 10 \text { daily } \\
\text { Adexolin m. } 10 \text { daily }\end{array}$ & - \\
\hline 9 & $\mathbf{M}$. & None & 6 months & Irritable & $\begin{array}{l}20 \text { May, } \\
23 \text { June, } \\
13 \text { Oct., }\end{array}$ & $\begin{array}{l}1948 \\
1948 \\
1948\end{array}$ & $\begin{array}{l}36 \\
58 \\
24\end{array}$ & Cakciferol 200,000 by 4 & Radiograph normal \\
\hline
\end{tabular}

TABUE 3

ANALYSIS OF CASES WITH SYMPTOMS AND A NORMAL PHOSPHATASE

\begin{tabular}{|c|c|c|c|c|c|c|c|c|c|}
\hline \multirow[b]{2}{*}{ No. } & \multirow[b]{2}{*}{ Sex } & \multirow[b]{2}{*}{ Vitamin D } & \multirow[b]{2}{*}{ Age } & \multirow[b]{2}{*}{ Signs } & \multicolumn{3}{|c|}{ Phosphatase Units } & \multirow[b]{2}{*}{ Treatment } & \multirow[b]{2}{*}{ Remarks } \\
\hline & & & & & Dat & & No. & & \\
\hline 1 & $\mathbf{M}$. & Given & 7 months & $\begin{array}{l}\text { Irritable } \\
\text { Now showed } \\
\text { B-F1 }\end{array}$ & $\begin{array}{l}10 \text { Aug., } \\
15 \text { Nov., }\end{array}$ & $\begin{array}{l}1948 \\
1948\end{array}$ & 24 & $\begin{array}{l}\text { No treatment given } \\
\text { Calciferol } 200,000 \text { by } 3\end{array}$ & Radiograph normal \\
\hline 2 & F. & Given & 1 yr. 3 months & $\begin{array}{l}\text { Delayed } \\
\text { dentition } \\
\text { F - ? }\end{array}$ & $\begin{aligned} 12 & \text { Dec., } \\
16 & \text { June, } \\
1 & \text { Sept., } \\
27 & \text { Oct., } \\
24 & \text { Nov., }\end{aligned}$ & $\begin{array}{l}1947 \\
1948 \\
1948 \\
1948 \\
1948\end{array}$ & $\begin{array}{l}20 \\
32 \\
60 \\
24 \\
22\end{array}$ & $\begin{array}{l}\text { No treatment given } \\
\text { Adexolin ml. } 5 \text { daily }\end{array}$ & Radiograph normal \\
\hline
\end{tabular}

in Bodansky units have shown that phosphatase activity rises from $7 \cdot 1$ units on the third day to 13.0 units by the fourth or fifth month, and then gradually declines to 11.5 units by the end of the third year, the normal adult range being 1 $15-4$ units.

Klasmer (1944) in his controls found a variation of 9-15 Bodansky units in children ranging in age from six months to two and a half years. It is not possible to convert Bodansky to King-Armstrong units, but as they both measure phosphatase activity, it is to be expected that the variation in one should be reflected by the other. If Corner's figure of up to $10 \pm 5$ units normal range for the infant is accepted, then it shows very little difference from the adult normal and does not mirror the rise which other observers have noted for Bodansky's method.
Further, the greatest rate of growth in length in a child, about eighteen inches, occurs during the first three years of life, dropping to less than half that figure for the next three years. It seems reasonable to expect the tremendous epiphyseal activity to be paralleled by a phosphatase activity greater than that found in the static adult. It is thought therefore that the figure of 20 units as the upper limit of normal for the first three years of life given by the control series in this paper is approximately correct.

A phenomenon discussed by Yieh and Wisler (1938) as well as by Josefsson is seen in some of the cases in this series, namely in table 1 nos. 1, 10, 12; in table 2 nos. $3,4,9$; and in table 3, no. 2 . With the institution of vitamin treatment, particularly of the 
TABUE 4

ANALYSIS OF CASES CLINICALLY DIAGNOSED AS RICKETS WITH NO BIOCHEMICAL CONFIRMATION

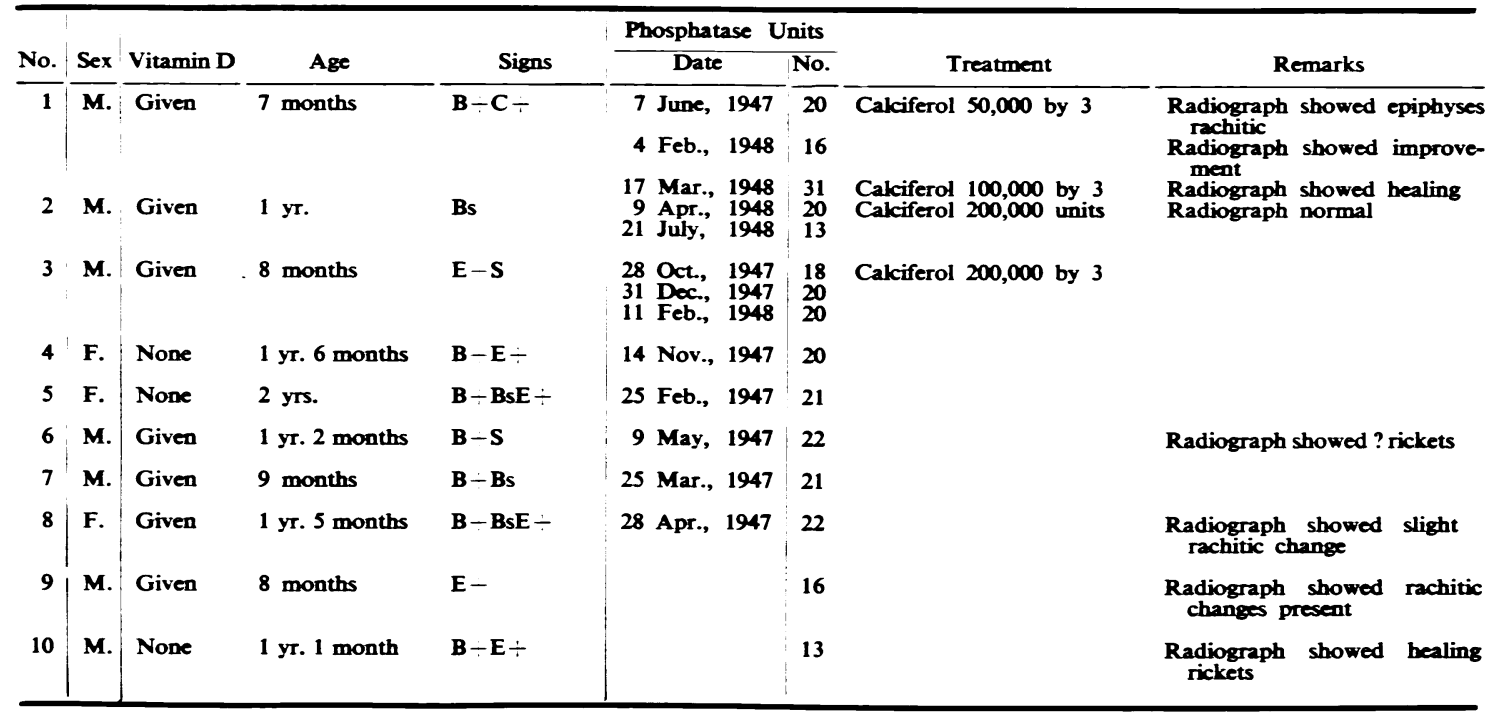

shock variety, there is first a fall in phosphatase activity, then a secondary rise, finally a slow fall to normal. This is assumed to be associated with the process of healing in more advanced cases. The usual reaction in milder types is a prompt drop to a point either near or within the normal range.

Dikshit and Patwardhan (1946) working on experimental rickets in puppies noted that the phosphatase started to rise slowly from the very beginning of vitamin $D$ deficiency. This is illustrated in table 2 by cases $1-9$ when symptoms which might have been due to early rickets were present. None of the usual stigmata were found on physical examination. The phosphatase activity averaged 35 units. It is interesting to note that the phosphatase findings in these very early cases were in the main in keeping with those which had definite signs. It is suggested that although a rise in phosphatase activity is diagnostic of early rickets, it cannot be used in this type of case as an index of the severity of vitamin $\mathrm{D}$ deficiency, confirming a similar finding of Morris et al. (1937).

Cases 1 and 2 (table 3 ) demonstrate the necessity of checking the phosphatase at frequent intervals when the diagnosis is entertained but the biochemical findings are equivocal. Clinical judgment had been swayed by the reported phosphatase level. Consequently no treatment had been given, with the result that three and six months later both biochemical and clinical rickets were present in each case.

Cases 1-10 (table 4) require separate consideration. Case 3 is probably an example of healed rickets in which the physical signs remain but the phosphatase sevel has returned to normal. In this case, large doses of ' calciferol' had no effect on the enzymatic activity. This has been suggested as diagnostic of healed rickets by Klasmer (1944). Cases 4-6 are difficult to classify because of a lack of fuller information. They could be cases of active rickets with a borderline phosphatase level, or of healed rickets with persistent physical signs. A dose of 200,000 units of calciferol and a phosphatase estimation three weeks later would probably have settled the point. This reaction is illustrated by cases 1 and 2 . Case 8 is probably borderline, and for nos. 9 and 10 no explanation is offered.

No attempt has been made to correlate radiological and biochemical findings, a difficulty experienced by Bodansky and Jaffe (1934) and appearing in this series as well. They found cases with a normal phosphatase content and radiological evidence of rickets, and a review of the cases presented here shows the same inconsistency. Radiological diagnosis of early rickets is renowned for its difficulty, and is one in which error is great even among the most highly skilled observers. The limitations of the radiologist in this respect are noted by Barnes and Carpenter (1937), and it is felt that too much reliance should not be based on $x$-ray examinations for diagnostic purposes in those cases where, at best, a radiograph can only be expected to show minimal changes.

\section{Summary}

An estimation of the plasma-alkaline-phosphatase by the King-Armstrong method in 56 controls gives a range of 11-20 units with an average of 17 for 
children between one month and three years of age. Over that age, the average approximates to the figure for adults.

In sixty-four cases of clinical rickets, blood phosphatase levels were evaluated, many of them serially before and after treatment. The most frequent diagnostic titre lay between 25-40 units.

The prompt response to specific therapy is shown. The raised blood phosphatase level due to shock therapy has been noted and discussed. The phosphatase level in very early cases showing symptoms but no signs averages 35 units.

The difficulties of diagnosis in borderline cases are mentioned, and it is suggested that a dose of calciferol, 200,000 units, followed by a further blood phosphatase estimation three weeks later may be of assistance in solving the problem. The difficulties of early radiological diagnoses are stressed, and it is suggested that the discrepancies which occur occasionally in cases of clinical rickets and a normal phosphatase may be due to the persistence of physical signs in healed rickets.

We are indebted to Dr. A. M. Rackow for his assistance in discussing the radiology of rickets.
REFERENCES

Barnes, D. J., and Carpenter, M. D. (1937). J. Pediat., $10,596$.

- Kaucher, M., and Munks, B. (1946). Amer. J. Dis. Child., 71, 622

- , and Munks, B. (1940). Proc. Soc. exp. Biol., 44, 327.

Bodansky, A., and Jaffe, H. L. (1934). Arch. intern. Med., 54, 88.

Brit. Paed. Assoc. (1944). Arch. Dis. Child., 19, 54.

Cantarow, A., and Trumper, M. (1945). Clin. Biochem.. 3rd ed., 198. Philadelphia.

Cecil, R. L. (1940). Text Book of Med., 5th ed., 645. Philadelphia.

Corner, B. D. (1944). Arch. Dis. Childh., 19, 68.

Dalyell, E. J., and Mackay, H. M. M., M.R.C. (1922). Spec. Rep. Ser., 77, 137.

Dikshit, P. K., and Patwardhan, V. N. (1946). Indian J. med. Res., 34, 263.

Josefsson, E. (1941). Ann. Paediatr., 157, 169.

Klasmer, R. (1944). Amer. J. Dis. Child., 67, 348.

May, E. W., and Wygant, T. M. (1939). Arch. Pediat., 56, 274.

Morris, N., and Peden, O. D. (1937). Quart. J. Med., n.s. 6, 211.

—, Stevenson, M. M. and Small, J. M. D. (1937). Arch. Dis. Childh., $12,45$.

Price, F. (1946). Text Book of Prac. Med., 7th ed., 486 et seq.

Rackow, A. M. (1949). Personal communication.

Yieh, V., and Wissler, O. (1938). Ann. Paediatr., 152, 348. 